ISTIGHNA, Vol. 3, No 1, Januari 2020 P-ISSN 1979-2824 E-ISSN 2655-8459

Homepage: http://e-journal.stit-islamic-village.ac.id/index.php/istighna

Lia Dwi Tresnani, Muhammad Khoiruzzadi

Program Pembiasaan Harian dalam Membentuk Karakter Siswa Ditinjau dari Perspektif

Psikologi Belajar

\title{
PROGRAM PEMBIASAAN HARIAN DALAM MEMBENTUK KARAKTER SISWA DITINJAU DARI PERSPEKTIF PSIKOLOGI BELAJAR
}

\author{
Lia Dwi Tresnani \\ dwilia5888@gmail.com \\ Universitas Islam Negeri Sunan Kalijaga Yogyakarta \\ Muhammad Khoiruzzadi \\ khoiruzzadie@gmail.com \\ Universitas Islam Negeri Sunan Kalijaga Yogyakarta
}

\begin{abstract}
This study aims to determine the program of daily habituation activities in shaping the character of students of SMP Negeri 6 Pekalongan City, looking for what characters are to be formed in each daily habituation activity program, and concepts in psychological learning theory in explaining the process of habituation activities in shaping student character. This research is included in the field research with a descriptive qualitative approach. The results of the study of daily habituation programs in SMP Negeri 6 Pekalongan City are scheduled and conditional, namely tadarus and prayers before KBM (religious and disciplinary), duha prayer (religious and responsibility), dzhuhur prayers (religious and responsibility), canteen honesty (honesty), orderly coming and going home (discipline and responsibility), orderly appearance (discipline and responsibility), respectful flags singing the national anthem, and folk songs (love of the motherland and national spirit), group class picket (care about the environment and responsibility), conditioning the cleanliness (care for the environment), separation of organic and non-organic waste (care for the environment and responsibility). From the daily habituation program can be explained psychological approach, especially with learning theories, including (1) changes in student behavior with habituation activities and carried out repeatedly will be a reinforcer in student behavior in addition to reward and punishment as a reminder process for students, (2) students' self-awareness in behaving because of changes in student behavior needs to be seen from the cognitive development of students. Some students are still in the level of concrete operations and most have entered the formal operational stage so students are able to think more mature and able to think logically and logically. In addition, changes in student behavior are formed due to the process of imitation and demonstration from teachers in particular, and friends at school in general. So the role of the teacher, the school environment and the cognitive abilities of students is an important key in shaping behavior.
\end{abstract}

Keywords: Daily Habituation Programs, Character, Learning Psychology

Abstrak: Penelitian ini bertujuan untuk mengetahui program kegiatan pembiasaan harian dalam membentuk karakter siswa SMP Negeri 6 Kota Pekalongan, mencari

Peer reviewed under reponsibility of STIT ISLAMIC VILLAGE.

(C) 2018 STIT ISLAMIC VILLAGE, All right reserved, This is an open access article under 32 the CC BY SA license (https://creativecommons.org/licenses/by-sa/4.0/) 
ISTIGHNA, Vol. 3, No 1, Januari 2020 P-ISSN 1979-2824 E-ISSN 2655-8459

Homepage: http://e-journal.stit-islamic-village.ac.id/index.php/istighna

Lia Dwi Tresnani, Muhammad Khoiruzzadi

Program Pembiasaan Harian dalam Membentuk Karakter Siswa Ditinjau dari Perspektif Psikologi Belajar

karakter apa yang hendak dibentuk dalam setiap program kegiatan pembiasaan harian, dan konsep dalam teori psikologi belajar dalam menjelaskan proses kegiatan pembiasaan dalam membentuk karakter siswa. Penelitian ini termasuk dalam penelitian lapangan dengan pendekatan kualitatif deskriptif. Hasil dari penelitian program pembiasaan harian di SMP Negeri 6 Kota Pekalongan ada yang bersifat terjadwal dan kondisional yaitu tadarus dan doa sebelum KBM (religius dan disiplin), solat dhuha (religius dan tanggung jawab), solat dzhuhur berjamaah (religius dan tanggung jawab), kantin kejujuran (kejujuran), tertib datang dan pulang (disiplin dan tanggung jawab), tertib berpenampilan (disiplin dan tanggung jawab), hormat bendera menyanyikan lagu kebangsaan, dan lagu daerah (cinta tanah air dan semangat kebangsaan), piket kelas berkelompok (peduli lingkungan dan tanggung jawab), pengondisian kebersihan (peduli lingkungan), pemisahan sampah organik dan non organik (peduli lingkungan dan tanggung jawab). Dari program pembiasaan harian dapat dijelaskan pendekatan psikologi khususnya dengan teori-teori belajar, diantaranya (1) perubahan tingkah laku siswa dengan kegiatan pembiasaan dan dilakukan secara berulang-ulang akan menjadi penguat dalam perilaku siswa selain itu reward dan punishment sebagai proses pengingat siswa, (2) kesadaran diri siswa dalam berperilaku karena perubahan tingkah laku siswa perlu dilihat dari perkembangan kognitif siswa. Beberapa siswa masih berada dalam tingkatan operasional konkret dan kebanyakan sudah masuk dalam tahapan operasional formal sehingga siswa mampu berpikir secara lebih matang dan mampu berpikir nalar dan logis. Selain itu, perubahan tingkah laku siswa terbentuk karena proses peniruan dan percontohan dari guru khususnya, dan teman-teman di sekolah secara umum. Jadi peran guru, lingkungan sekolah dan kemampuan kognitif siswa menjadi kunci penting dalam pembentukan perilaku.

\section{Kata Kunci: Program Pembiasaan Harian, Karakter, Psikologi Belajar}

\section{A. PENDAHULUAN}

Tujuan pendidikan nasional sebagaimana tertuang dalam UU No. 20 Tahun 2003 adalah mengembangkan potensi peserta didik agar menjadi manusia yang beriman dan bertakwa kepada Tuhan Yang Maha Esa, berakhlak mulia, sehat, berilmu, cakap, kreatif, mandiri, dan menjadi warga negara yang demokaratis serta bertanggung jawab (Sistem Pendidikan Nasional bab 2 pasal 3). Untuk mencapai tujuan nasional tersebut maka dibuatlah sistem pendidikan yang berkarakter (Panduan Pendidikan Karakter untuk SMP, Dikdasmen, Kemendiknas, 2010). Pendidikan karakter tidak hanya mengajarkan mana yang benar dan mana yang salah kepada siswa, tetapi lebih dari itu pendidikan karakter menanamkan kebiasaan tentang yang baik sehingga siswa paham, mampu merasakan, dan mau melakukan 
ISTIGHNA, Vol. 3, No 1, Januari 2020 P-ISSN 1979-2824 E-ISSN 2655-8459

Homepage: http://e-journal.stit-islamic-village.ac.id/index.php/istighna

Lia Dwi Tresnani, Muhammad Khoiruzzadi

Program Pembiasaan Harian dalam Membentuk Karakter Siswa Ditinjau dari Perspektif Psikologi Belajar

yang baik. ${ }^{1}$ Selanjutnya, pendidikan karakter merupakan usaha yang disengaja untuk membantu seseorang memahami, menjaga, dan berperilaku yang sesuai dengan nilai-nilai karakter mulia. ${ }^{2}$ Adapun karakter tersusun dari tiga bagian yang saling berhubungan, yaitu pengetahuan moral, perasaan moral, dan perilaku moral. ${ }^{3}$ Dari hal tersebut di atas, maka penerapan pendidikan karakter harus dilakukan dari pusat sampai ke daerah.

Pemerintah Kota Pekalongan menyadari betul kondisi remaja kasus kekerasan yang dilakukan siswa SMP di Kota Pekalongan. Data yang masuk di Unit PPA Polres Pekalongan Kota pada Tahun 2016 berupa kekerasan fisik dan kekerasan seksual. Remaja yang kurang kuat penanaman agama dan keimanannya akan cenderung mengiyakan terhadap nilai yang sebenarnya berlawanan dengan nilai agama. ${ }^{4} \mathrm{Hal}$ ini disebabkan kemampuan penalaran moral yang masih labil ${ }^{5}$, sehingga pendidikan karakter perlu diterapkan di sekolah, baik dari tingkat dasar, menengah dan tinggi. Dan tak kalah penting adalah siswa yang bermasalah perlu dilibatkan dan diajak berdiskusi dalam penyelesaian masalahnya. ${ }^{6}$

Salah satu SMP yang menyandang sekolah yang berbasis karakter adalah SMP Negeri 6 Kota Pekalongan. Selain itu, SMP Negeri 6 Kota Pekalongan merupakan sekolahan yang termasuk favorit dan diminati banyak orang tua untuk bisa menyekolahkan anaknya ke SMP tersebut. ${ }^{7}$ SMP Negeri 6 Kota Pekalongan

${ }^{1}$ Marzuki, Pendidikan Karakter Dan Pengintegrasiannya Dalam Pembelajaran, STAIN Kediri, 2012

${ }^{2}$ Mike Frye, Character Education: Informational Handbook and Guide for Support and Implementation of the Student Citizent Act of 2001, North Carolina: Public Schools of North Carolina., 2002

3 Thomas Lickona, Educating for Character: How Our School Can Teach Respect and Responsibility, New York, Toronto, London, Sydney,. Aucland: Bantam books., 1991

${ }^{4}$ Yuniati, Ani, Suyahmo, and Juhadi, Perilaku Menyimpang Dan Tindak Kekerasan Siswa SMP Di Kota Pekalongan, Journal of Educational Social Studies 6, no. 1, 2017

${ }^{5}$ Kirsi Tirri, and Leila Pehkonen, The Moral Reasoning and Scientific Argumentation of Gifted Adolescents, Journal of Advanced Academics 13, no. 3, 2002

${ }^{6}$ L. Diana Mitra, dan Steven Jay Gross, Increasing Student Voice in High School Reform: Building Partnerships, Improving Outcomes, Journal Educational Management Administration \& Leadership 37, no. 4, 2009

${ }^{7}$ Okezone, SMP Unggulan Pekalongan Kebanjiran Calon Siswa, Berita, 2016. Accessed November 20, 2019. https://news.okezone.com/read/2016/06/21/65/1421510 
ISTIGHNA, Vol. 3, No 1, Januari 2020 P-ISSN 1979-2824 E-ISSN 2655-8459

Homepage: http://e-journal.stit-islamic-village.ac.id/index.php/istighna

Lia Dwi Tresnani, Muhammad Khoiruzzadi

Program Pembiasaan Harian dalam Membentuk Karakter Siswa Ditinjau dari Perspektif Psikologi Belajar

pernah menjadi juara dua lomba sekolah berkarakter kebangsaan jenjang SMP tingkat provinsi Jawa Tengah pada tahun 2012 dan .juara satu lomba sekolah berkarakter kebangsaan jenjang SMP tingkat Kota Pekalongan pada tahun 2014. Hal ini memang menjadi hal yang penting di SMP Negeri 6 Kota Pekalongan, sebagaimana tertuang pula dalam visi SMP Negeri Kota Pekalongan yaitu terwujudnya sekolah unggul berwawasan lingkungan yang mengembangkan insan cerdas, berahklak mulia dan cinta tanah air. Dalam mendapatkan status sekolah berkarakter pasti dibutuhkan perencanaan yang matang dan pelaksanaan yang maksimal.

Keberhasilan membentuk karakter yang baik pada siswa dalam suatu lembaga pendidikan tidak terlepas dari peran guru, orang tua ${ }^{8}$ dan lingkungan sekitar. ${ }^{9}$ Implementasi pendidikan karakter dapat dilakukan melalui keterpaduan antara pembentukan karakter dengan pembelajaran, manajemen sekolah, dan kegiatan ekstrakurikuler. ${ }^{10}$. Implementasi tersebut dapat dibagi lagi ke dalam program-program kegiatan yang bersifat harian, mingguan, bulanan dan tahunan. Setiap program kegiatan yang dilakukan oleh sekolah memiliki tujuan tersendiri dalam hal ini membentuk karakter tertentu, seperti kegiatan upacara bendera dapat membentuk karakter disiplin, tanggung jawab, semangat kebangsaan serta percaya diri. ${ }^{11}$

Menurut Kementerian Pendidikan Nasional, nilai karakter bangsa terdiri atas sebagai berikut. yaitu: (1) Religius, (2) Jujur, (3) Toleransi, (4) Disiplin, (5) Kerja keras, (6) Kreatif, (7) Mandiri, (8) Demokratis, (9) Rasa Ingin Tahu, (10) Semangat Kebangsaan, (11) Cinta Tanah Air, (12) Menghargai Prestasi, (13)

\footnotetext{
${ }^{8}$ Yuliana Margaretha Tokuan, Peran Guru Dalam Pembentukan Kepribadian Disiplin Siswa SMP Negeri 11 Kota Pontianak, Jurnal Pendidikan dan Pembelajaran Khatulistiwa 5, no. 1, 2016

9 Ali Ramdhani, Lingkungan Pendidikan Dalam Implementasi Pendidikan Dalam Implementasi Pendidikan Karakter, Jurnal Pendidikan UNIGA 8, no. 1, 2014

${ }^{10}$ Reza Armin Abdillah Dalimunthe, Strategi Dan Implementasi Pelaksanaan Pendidikan Karakter Di SMP N 9 Yogyakarta, Jurnal Pendidikan Karakter 5, no. 1, 2015;

${ }^{11}$ Agista Rizky Ridha Ayu and I Made Suwanda, Pembentukan Karakter Siswa SMP Negeri 6 Mojokorto Melalui Kegiatan Upacara Bendera, Kajian Moral dan Kewarganegaraan, 1, no. 1, 2013
} 
ISTIGHNA, Vol. 3, No 1, Januari 2020 P-ISSN 1979-2824 E-ISSN 2655-8459

Homepage: http://e-journal.stit-islamic-village.ac.id/index.php/istighna

Lia Dwi Tresnani, Muhammad Khoiruzzadi

Program Pembiasaan Harian dalam Membentuk Karakter Siswa Ditinjau dari Perspektif Psikologi Belajar

Bersahabat/Komunikatif, (14) Cinta Damai, (15) Gemar Membaca, (16) Peduli Lingkungan, (17) Peduli Sosial, \& (18) Tanggung Jawab. ${ }^{12}$

SMP Negeri 6 Kota Pekalongan memiliki beberapa program kegiatan pembiasaan harian yang dibuat dengan tujuan untuk membentuk karakter siswa. ${ }^{13}$ Kegiatan pembiasaan yang dilakukan secara terus menerus dan berulang-ulang akan membentuk karakter tertentu yang diharapkan sesuai dengan tujuan dan pengulangan-pengulangan tersebut berfungsi sebagai penguat. ${ }^{14}$ Akan tetapi, dengan adanya proses pembiasaan tersebut masih ada siswa yang melanggar atau tidak melakukan kegiatan yang sudah diprogramkan tersebut, sehingga hukuman akan diterima oleh siswa tersebut. Penggunaan konsekuensi yang menyenangkan (reward) dan tidak menyenangkan (punishment) untuk mempertahankan perilaku yang baik atau mengubah perilaku yang tidak baik untuk disadarkan kembali ke perilaku yang baik. ${ }^{15}$ Sehingga perilaku yang dibentuk dengan cara tersebut masuk dalam teori belajar behavioristik. ${ }^{16}$

Berbeda dengan aliran behavioristik, menurut aliran kognitif, setiap siswa memiliki kemampuan intelektual yang berbeda-berbeda sesuai dengan perkembangan kognitifnya. ${ }^{17}$ Selain itu, dalam proses pembentukan perilaku siswa sebenarnya dibutuhkan kemampuan berpikir dan mengatur dirinya sendiri sehingga ia tidak hanya dibentuk melalui lingkungan saja tetapi dapat mengontrol dan mengendalikan lingkungan tersebut ${ }^{18}$, dan pemahaman yang dibawakan oleh Bandura disebut dengan teori belajar sosial.

12 Anas Salahudin dan Irwanto Alkrienchie, Pendidikan Karakter: Pendidikan Berbasis Agama dan Budaya Bangsa, Bandung : Pustaka Setia, 2013

${ }^{13}$ Wawancara NH selaku Guru PAI SMP, 2019

14 Toeti Soekamto and Udin Saripudin Winaputra, Teori Belajar Dan Model-Model Pembelajaran, Jakarta: Dikti, 1997

15 Robert E. Slavin, Psikologi Pendidikan: Teori Dan Praktik, Translated by Marianto Samosir. Jakarta: PT Indeks, 2006

${ }^{16}$ M. Dalyono, Psikologi Pendidikan, Jakarta: Rineka Cipta, 2007

17 Hergenhanhn B.R. Dan Matthew H.Olson, Theories of Learning, Terj. Tri Wibowo. Jakarta : Prenada Media Group, 2010

${ }^{18}$ Rismayati and Rolina, Pencarian Jati Diri Melalui Proses Belajar Dan Pengalaman, Yogyakarta: SPS UGM, 2012 
ISTIGHNA, Vol. 3, No 1, Januari 2020 P-ISSN 1979-2824 E-ISSN 2655-8459

Homepage: http://e-journal.stit-islamic-village.ac.id/index.php/istighna

Lia Dwi Tresnani, Muhammad Khoiruzzadi

Program Pembiasaan Harian dalam Membentuk Karakter Siswa Ditinjau dari Perspektif Psikologi Belajar

Penelitian ini bertujuan untuk mengetahui program kegiatan pembiasaan dalam membentuk karakter siswa SMP Negeri 6 Kota Pekalongan, mencari karakter apa yang hendak dibentuk dalam setiap program kegiatan pembiasaan, dan konsep yang berbeda-beda dalam teori psikologi belajar dalam menjelaskan proses kegiatan pembiasaan dalam membentuk karakter siswa.

\section{B. METODE PENELITIAN}

Dalam penelitian ini termausk dalam penelitian lapangan (field research). Pendekatan yang digunakan adalah pendekatan kualitatif deskriptif, yaitu prosedur penelitian yang menghasilkan data deskriptif berupa kata-kata tertulis atau lisan dari orang-orang dan perilaku yang dapat diamati, dengan sumber datanya yang terdiri dari data primer dan data sekunder. Untuk data primer adalah data yang diperoleh dari hasil wawancara dengan guru PAI dan hasil observasi perilaku siswa SMP Negeri 6 Kota Pekalongan. Sedangkan data sekunder diperoleh dari dokumentasi baik berupa teks maupun dokumen lain yang terkait dengan fokus penelitian di SMP Negeri 6 Kota Pekalongan. Setelah data tersebut terkumpul, langkah selanjutnya adalah menganalasisnya. Langkah peneliti dalam menganalisis data tersebut dimulai dengan menelaah seluruh data yang telah terkumpul. Data tersebut tentunya sangat banyak, setelah dibaca dan dipelajari, maka langkah berikutnya adalah melibatkan tiga komponen analisis, yaitu: reduksi data, penyajian data, dan penarikan kesimpulan.

\section{HASIL PENELITIAN DAN PEMBAHASAN}

\section{Hasil Penelitian}

Berdasarkan hasil penelitian, bentuk program pembiasaan harian yang ada di SMP Negeri 6 Kota Pekalongan ada 10 kegiatan pembiasaan, diantaranya:

\section{a. Tadarus dan do'a sebelum KBM}

Kegiatan tadarus dan doa bersama sebelum KBM telah terlaksana secara terjadwal di SMP Negeri 6 Kota Pekalongan yaitu dimulai pukul 07.00. Dalam pelaksanaannya siswa-siswa sudah bisa mandiri untuk melaksanakannya 
ISTIGHNA, Vol. 3, No 1, Januari 2020 P-ISSN 1979-2824 E-ISSN 2655-8459

Homepage: http://e-journal.stit-islamic-village.ac.id/index.php/istighna

Lia Dwi Tresnani, Muhammad Khoiruzzadi

Program Pembiasaan Harian dalam Membentuk Karakter Siswa Ditinjau dari Perspektif Psikologi Belajar

seperti di kelas VIII dan IX, untuk kelas VII karena perlu penyesuaian maka harus lebih intensif untuk dibimbing oleh guru. Namun bapak ibu guru tetap mengawasi dan menemani siswa kelas VIII dan IX untuk bertadarus dan berdoa pagi sebelum KBM. Dalam pelaksanaan tadarus, penulis masih menemukan siswa yang mengobrol saat tadarus ketika tidak diawasi guru. Tetapi, hal itu terjadi hanya pada sebagian kecil saja dari keseluruhan siswa. Untuk mengantisipasi hal tersebut guru mata pelajaran jam pertama yang akan memantau langsung sehingga anak-anak dibiasakan untuk tetap tertib.

Surat yang dibaca siswa setiap harinya berurutan dari al-Baqarah sampai khatam. Setiap hari siswa membawa al-Qur'an sendiri-sendiri dari rumah, tapi ada pula yang membawa dari rumah kemudian ditinggal di laci kelas supaya tidak membawa setiap hari. Setelah tadarus selesai dilanjut dengan membaca shalawat nariyah bersama-sama sebanyak tiga kali dengan dipandu oleh anak yang bertugas tadarus.

Karakter yang diharapkan dari pihak sekolah dalam kegiatan ini terhadap siswa-siswinya adalah religius dan disiplin. Adapun yang dimaksud dari karakter religius yaitu sikap dan perilaku yang patuh dalam melaksanakan ajaran agama yang dianutnya, toleran terhadap pelaksanaan ibadah agama lain, dan hidup rukun dengan pemeluk agama lain. Sedangkan yang dimaksud dengan karakter disiplin yaitu tindakan yang menunjukkan perilaku tertib dan patuh pada berbagai ketentuan dan peraturan. ${ }^{19}$

\section{b. Solat dhuha}

Solat dhuha sudah memiliki jadwal tersendiri, namun dalam pelaksanaannya tidak sama dengan apa yang telah dijadwalkan. Serta sebagian besar anak-anak yang melaksanakan shalat dhuha yakni Siswa kelas IX dan hanya sebagian kecil saja siswa kelas VII dan VIII. Hal ini masih atas dasar kesadaran diri dalam dan tuntutan akan melaksanakan ujian bagi kelas IX. Di samping itu, tidak adanya pengabsenan atau pendataan terhadap siswa dalam

${ }^{19}$ Muhammad Fadhillah dan Lilif Mualifatu Khorida, Pendidikan Karakter Anak Usia Dini, Yogyakarta: Ar-Ruzz Media, 2013 
ISTIGHNA, Vol. 3, No 1, Januari 2020 P-ISSN 1979-2824 E-ISSN 2655-8459

Homepage: http://e-journal.stit-islamic-village.ac.id/index.php/istighna

Lia Dwi Tresnani, Muhammad Khoiruzzadi

Program Pembiasaan Harian dalam Membentuk Karakter Siswa Ditinjau dari Perspektif Psikologi Belajar

pelaksanaan solat dhuha. Sehingga tidak diketahui secara pasti siswa mana saja yang sudah maupun yang belum melaksanakan solat dhuha.

Karakter yang diharapkan dari pihak sekolah dalam kegiatan ini terhadap siswa-siswinya adalah religius dan disiplin adalah religius dan tanggung jawab. Adapun yang dimaksud dari karakter religius yaitu sikap dan perilaku yang patuh dalam melaksanakan ajaran agama yang dianutnya, toleran terhadap pelaksanaan ibadah agama lain, dan hidup rukun dengan pemeluk agama lain. Sedangkan yang dimaksud dengan karakter bertanggungjawab adalah sikap dan perilaku seseorang untuk melaksanakan tugas dan kewajibannya, yang seharusnya dia lakukan, terhadap diri sendiri, masyarakat, lingkungan (alam, sosial dan budaya), negara dan Tuhan Yang Maha Esa. ${ }^{20}$

\section{c. Solat dzhuhur berjamaah}

Sama seperti shalat dhuha, shalat dzuhur berjamaah juga sudah ada jadwalnya untuk kelas mana saja yang melaksanakan sholat terlebih dahulu kemudian guru siapa yang menjadi imamnya. Pembagian jadwal kelas masih menjadi kendala dikarenakan tempat sholat atau mushola yang ukurannya terbatas dan tidak sesuai dengan jumlah keseluruhan siswa. Namun dalam pelaksanaanya nyatanya siswa yang melaksanakan shalat dzuhur berjamaah tidak sesuai dengan jadwal yang tertera.

Tidak jarang terlihat siswa yang mungkin kelasnya tidak ada guru atau sudah selesai terlebih dahulu kemudian mereka melaksanakan shalat dzuhur, karena bel istirahat jam kedua setelah adzan dzuhur berkumandang. Dan juga tidak semua siswa melaksanakan shalat dzuhur pada istirahat kedua, sebagian dari mereka memilih jajan terlebih dahulu dan melaksanakan shalat dzuhur ketika sudah pulang sekolah. Adapun karakter yang diharapkan dari pihak sekolah dalam kegiatan ini terhadap siswa-siswinya adalah religius dan tanggung jawab.

\section{d. Kantin kejujuran}

${ }^{20}$ Ibid., 
ISTIGHNA, Vol. 3, No 1, Januari 2020 P-ISSN 1979-2824 E-ISSN 2655-8459

Homepage: http://e-journal.stit-islamic-village.ac.id/index.php/istighna

Lia Dwi Tresnani, Muhammad Khoiruzzadi

Program Pembiasaan Harian dalam Membentuk Karakter Siswa Ditinjau dari Perspektif Psikologi Belajar

Kantin kejujuran setiap harinya selalu ramai dikunjungi siswa. Adapun para siswa mengambil sendiri barang atau makanan maupun minuman yang dibutuhkannya. Menurut penuturan penjaga kantin kejujuran, keuangan di kantin kejujuran tidak pernah merugi dan seringnya untung besar setiap tahunnya. Penjaga kantin juga kerap menemukan anak-anak yang berlaku jujur ketika uang kembaliannya kelebihan atau menemukan uang yang jatuh diarea kantin. Anak-anak juga tertib dalam pembelian buku LKS, tempat buku LKS berada di luar kantin kejujuran dan ketika ada anak yang ingin membeli LKS, penjaga kantin hanya memberikan kunci ruangannya saja kemudian siswa mengambil sendiri buku apa yang diperlukan. Setelah itu siswa melaporkan buku apa saja yang dibelinya dan membayar pada penjaga kantin kejujuran. Dalam pembelian LKS, tidak ada petugas yang menjaga. Siswa mengambil sendiri LKS yang hendak dibelinya kemudian melaporkannya. Adapun karakter yang diharapkan dari pihak sekolah dalam kegiatan ini terhadap siswasiswinya adalah adalah kejujuran. Kejujuran yang dimaksud adalah perilaku yang didasarkan pada upaya menjadikan dirinya sebagai orang yang selalu dapat dipercaya dalam perkataan, tindakan, dan pekerjaan. ${ }^{21}$

\section{e. Tertib datang dan pulang}

Siswa wajib datang sebelum pukul 07.00 pagi, apabila melewati jam tersebut maka gerbang sekolah akan ditutup dan siswa yang terlambat harus menunggu di luar gerbang sampai kegiatan tadarus dan doa berakhir. Setelah itu siswa yang terlambat harus mencatat namanya di BK dan kemudian mendapatkan sanksi atas keterlambatannya. Begitupun ketika jam sekolah masih berlangsung, siswa yang ada keperluan keluar sekolah wajib melapor kepada BK kemudian tembus ke satpam baru setelah itu siswa diperkenankan untuk keluar sekolah. Namun waktunyapun dibatasi sesuai dengan keperluan siswa. Bagi siswa yang tidak berangkat juga wajib untuk memberikan keterangan yang jelas ke sekolah, apabila tidak mengindahkan maka akan

\footnotetext{
${ }^{21}$ Ibid.,
} 
ISTIGHNA, Vol. 3, No 1, Januari 2020 P-ISSN 1979-2824 E-ISSN 2655-8459

Homepage: http://e-journal.stit-islamic-village.ac.id/index.php/istighna

Lia Dwi Tresnani, Muhammad Khoiruzzadi

Program Pembiasaan Harian dalam Membentuk Karakter Siswa Ditinjau dari Perspektif Psikologi Belajar

mendapatkan teguran dan diminta untuk menemui guru yang mengajar pada hari ia tidak berangkat untuk menanyakan tugas pada hari tersebut.

Karakter yang diharapkan dari pihak sekolah dalam kegiatan ini terhadap siswa-siswinya adalah disiplin dan tanggung jawab. Disiplin yang dimaksud adalah tindakan yang menunjukkan perilaku tertib dan patuh pada berbagai ketentuan dan peraturan. Sedangkan tanggung jawab adalah sikap dan perilaku seseorang untuk melaksanakan tugas dan kewajibannya, yang seharusnya dia lakukan, terhadap diri sendiri, masyarakat, lingkungan (alam, sosial dan budaya), negara dan Tuhan Yang Maha Esa. ${ }^{22}$

\section{f. Tertib berpenampilan}

Setiap harinya guru selalu mengecek penampilan siswa. Mulai dari kerapihan rambut bagi yang laki-laki sampai pada kelengkapan atribut yang wajib digunakan siswa. Guru biasanya mengecek ketika menyambut siswa digerbang sekolah, ketika siswa bersalaman maka guru sambil mengecek kerapihan siswa. Apabila ada yang tidak sesuai maka guru akan menegurnya dan kemudian melaporkan pada wali kelas supaya mendapatkan pembinaan. Guru ketika masuk kelas juga demikian, terutama guru mata pelajaran jam pertama yang mengecek kelengkapan atribut siswa dan kerapihan pakaian. Apabila tidak sesuai maka akan menjadi catatan bagi penilain sikap dan dilaporkan ke wali kelas untuk kemudian dibina. Tidak hanya ketika datang dan di kelas, kerapihan siswa juga diperiksa ketika upacara bendera hari Senin. Siswa yang kebetulan atributnya tidak lengkap maka akan mendapatkan sanksi berupa pengasingan barisan ketika upacara. Adapun karakter yang dibentuk dalam kegiatan ini adalah disiplin dan tanggung jawab.

\section{g. Hormat bendera, menyanyikan lagu kebangsaan dan lagu daerah}

Pada jam pertama dan jam terakhir siswa dibiasakan untuk menyanyikan lagu nasional dan lagu daerah. Adapun lagu nasional dinyanyikan ketika awal jam pelajaran pertama. Sedangkan lagu daerah dinyanyikan ketika jam mata pelajaran terakhir berakhir. Urutannya sebelum bernyanyi yakni ketua kelas

${ }^{22}$ Ibid., 
ISTIGHNA, Vol. 3, No 1, Januari 2020 P-ISSN 1979-2824 E-ISSN 2655-8459

Homepage: http://e-journal.stit-islamic-village.ac.id/index.php/istighna

Lia Dwi Tresnani, Muhammad Khoiruzzadi

Program Pembiasaan Harian dalam Membentuk Karakter Siswa Ditinjau dari Perspektif Psikologi Belajar

terlebih dahulu menyiapkan teman-temannya untuk berdoa "bersiap! Berdoa mulai." Setelah doa selesai ketua kelas kembali mengaba-aba untuk berdiri, setelah semua siswa berdiri maka ketua kelas kembali mengaba-aba untuk hormat pada bendera "kepada sang merah putih, hormat grak!" setelah selesai ketua kelas menginstruksi kembali "siap grak!”.

Ketua kelas melapor kepada guru bahwa pelajaran siap di mulai. Setelah itu anak yang bertugas untuk memandu bernyanyi maju ke depan. Adapun lagu yang dinyanyikan setiap harinya berganti-ganti sesuai jadwalnya dan pemandunyapun dari kalangan siswa bergantian berdasarkan urutan absen. Setelah memandu bernyanyi maka petugas kembali ke tempat duduknya. Kemudian dilanjutkan dengan menghafalkan visi misi sekolah. Sedangkan untuk menyanyikan lagu daerah urutannya sama seperti jam awal ketika menyanyikan lagu nasional hanya saja tidak ada sesi untuk menghafalkan visi misi.

Karakter yang diharapkan dari pihak sekolah dalam kegiatan ini terhadap siswa-siswinya adalah adalah cinta tanah air dan semangat kebangsaan. Maksud dari cinta tanah air adalah cara berpikir, bersikap, dan berbuat yang menunjukkan kesetiaan, kepedulian, dan penghargaan yang tinggi terhadap bahasa, lingkungan fisik, sosial, budaya, ekonomi, dan politik bangsa. Sedangkan semangat kebangsaan adalah cara berpikir, bertindak, dan berwawasan yang menempatkan kepentingan bangsa dan negara di atas kepentingan diri dan kelompoknya. ${ }^{23}$

\section{h. Piket kelas berkelompok}

Sebelum pulang sekolah atau pagi sebelum bel masuk berbunyi siswa melaksanakan piket kelas. Piket kelas sudah ada jadwalnya setiap hari dan dilaksanakan secara berkelompok. Siswa membagi secara mandiri tugas-tugas yang harus dilakukan setiap anggota piket, sehingga pekerjaan akan lebih cepat selesai. Bagi siswa yang enggan melaksanakan piket maka akan dikenai sanksi yang telah disepakati sebelumnya oleh seluruh anggota kelas. Piket kelas ini

${ }^{23}$ Ibid., 
ISTIGHNA, Vol. 3, No 1, Januari 2020 P-ISSN 1979-2824 E-ISSN 2655-8459

Homepage: http://e-journal.stit-islamic-village.ac.id/index.php/istighna

Lia Dwi Tresnani, Muhammad Khoiruzzadi

Program Pembiasaan Harian dalam Membentuk Karakter Siswa Ditinjau dari Perspektif Psikologi Belajar

didukung pelaksanaannya oleh adanya Pengandisian Kebersihan yang setiap hari dilaksanakan guru, sehingga membuat anak-anak semakin termotivasi untuk selalu bersih kelasnya.

Karakter yang diharapkan dari pihak sekolah dalam kegiatan ini terhadap siswa-siswinya adalah adalah peduli lingkungan dan tanggung jawab. Maksud dari peduli lingkungan adalah sikap dan tindakan yang selalu berupaya mencegah kerusakan lingkungan alam di sekitarnya dan mengembangkan upaya-upaya untuk memperbaiki kerusakan alam yang sudah terjadi. ${ }^{24}$

\section{i. Pengondisian kebersihan}

Setiap hari guru yang bertugas berkeliling untuk menilai kebersihan dan keindahan setiap kelas. Guru yang bertugas sudah memegang form yang berisi kriteria dari kebersihan dan keindahan kelas. Adapun hasil nilai setiap kelas nantinya akan direkap dan diumumkan pada setiap upacara bendera Senin satu minggu sekali. Dan untuk kelas yang keluar sebagai kelas terbersih akan mendapatkan hadiah. Apabila dapat bertahan selama satu bulan maka akan mendapatkan piala bergilir. Adapun karakter diharapkan dari pihak sekolah dalam kegiatan ini terhadap siswa-siswinya adalah peduli lingkungan.

\section{j. Pemisahan sampah organik dan non organik}

Siswa setiap harinya dihimbau untuk membuang sampah sesuai dengan jenisnya. Adapun tempat sampah yang tersedia di sekolahpun sebagian besar sudah ada keterangan antara organik dan non organik. Meskipun begitu, masih ada beberapa tempat sampah yang isinya tidak sesuai namanya. Misalnya tempat sampah bertuliskan organik ternyata di dalamnya tidak hanya terdapat daun dan sejenisnya tetapi juga ada bekas plastik es dan gelas plastik yang seharusnya tidak dibuang di tempat sampah tersebut. Adapun karakter diharapkan dari pihak sekolah dalam kegiatan ini terhadap siswa-siswinya adalah adalah peduli lingkungan dan tanggung jawab.

\section{Pembahasan}

${ }^{24}$ Ibid., 
ISTIGHNA, Vol. 3, No 1, Januari 2020 P-ISSN 1979-2824 E-ISSN 2655-8459

Homepage: http://e-journal.stit-islamic-village.ac.id/index.php/istighna

Lia Dwi Tresnani, Muhammad Khoiruzzadi

Program Pembiasaan Harian dalam Membentuk Karakter Siswa Ditinjau dari Perspektif Psikologi Belajar

Program pembiasaan harian yang dibuat oleh pihak SMP Negeri 6 Kota Pekalongan berjalan sesuai apa yang diharapkan dengan tujuan untuk membentuk karakter siswa sesuai dengan kegiatan-kegiatan pembiasaannya. Dari beberapa program pembiasaan harian yang ada di SMP Negeri 6 Kota Pekalongan dapat dibagi berdasarkan sifat pelaksanaannya yaitu terjadwal dan kondisional. Jadi kegiatan pembiasaan harian yang bersifat terjadwal, semua siswa harus melakukan kegiatan tersebut secara serempak kecuali kegiatankegiatan ke-Islaman yang tidak bisa dilakukan oleh siswa yang non muslim, seperti tadarus al-Qur'an, solat dhuha dan solat dhuhur berjamaah. Sedangkan kegiatan pembiasaan harian yang sifatnya tidak terjadwal atau kondisional di sini maksudnya adalah kegiatan pembiasaan hariaan yang belum tentu semua siswa akan melakukan kegiatan ini atau semua siswa melakukan kegiatan pembiasaan ini namun waktu pelaksanaan tiap siswa berbeda-beda, misalnya ada sebagian siswa yang di hari tertentu tidak jajan ke kantin kejujuran dan belum tentu semua siswa membuang sampah pada jam yang sama.

Kegiatan pembiasaan harian baik yang sifatnya terjadwal maupun kondisional itu dilakukan untuk mengubah perilaku yang tidak baik menjadi baik atau mempertahankan perilaku yang sudah baik agar tetap baik, dan harapannya menjadi lebih baik. Perubahan tingkah laku ini bisa dijelaskan dengan sudut pandang psikologi dan pendidikan. Dari program pembiasaan harian yang sudah dilakukan SMP Negeri 6 Kota Pekalongan, akan diperlihatkan secara sederhana tabel mengenai kegiatan pembiasaan harian yang sifatnya terjadwal dan kondisional dalam membentuk perilaku dan karakter yang sesuai dengan kegiatan tersebut. Sebagaimana disajikan pada tabel 1 .

Tabel 1. Program Pembiasaan Harian SMP Negeri 6 Kota Pekalongan

\begin{tabular}{|l|l|l|}
\hline Program Harian & Nama Kegiatan & Karakter \\
\hline $\begin{array}{l}\text { Program harian yang } \\
\text { terjadwal }\end{array}$ & a. Tadarus dan doa sebelum & a. Religius, disiplin \\
& KBM & \\
& b. Solat dhuha & b. Religius, tanggung jawab \\
& c. Solat dzuhur berjamaah & c. Religius, tanggung jawab \\
\hline
\end{tabular}


ISTIGHNA, Vol. 3, No 1, Januari 2020 P-ISSN 1979-2824 E-ISSN 2655-8459

Homepage: http://e-journal.stit-islamic-village.ac.id/index.php/istighna

Lia Dwi Tresnani, Muhammad Khoiruzzadi

Program Pembiasaan Harian dalam Membentuk Karakter Siswa Ditinjau dari Perspektif Psikologi Belajar

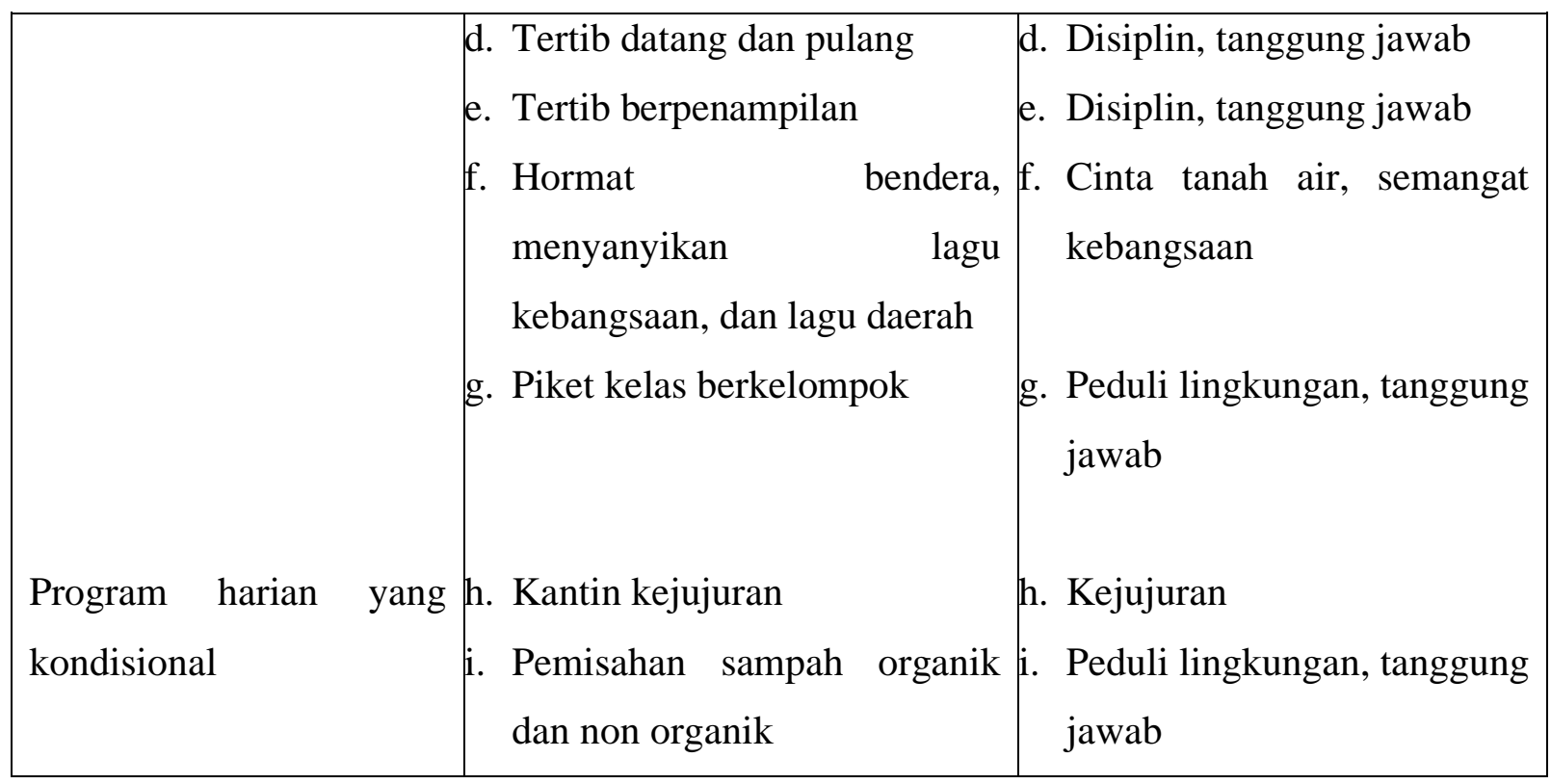

Dari kegiatan pembiasaan harian di atas, setidaknya bisa dijelaskan dengan menggunakan pendekatan psikologi khususnya dengan teori-teori belajar. Penulis akan membagi dalam dua bagian untuk menjelaskan kegiatan pembiasaan harian dalam membentuk perilaku siswa sesuai dengan karakter yang diharapkan sesuai dengan kegiatan pembiasaan harian tersebut.

\section{a. Pembiasaan Siswa dalam Melakukan Program Harian}

Program pembiasaan harian yang bersifat terjadwal maupun kondisional yang dilakukan SMP Negeri 6 Kota Pekalongan, setidaknya bisa dijelaskan dengan teori conditioning (upaya pengkondisian). Peranan siswa yang hendak dibentuk karakternya, sejatinya siswa itu bersifat pasif, dan pihak sekolah perlu mengadakan stimulus-stimulus yang berupa program pembiasaan harian tersebut, sehingga siswa akan merespon dari adanya stimulus yang berupa program pembiasaan harian tersebut. Hal ini akan menjadi sebuah masalah baru jika program tersebut tidak dilakukan secara terus menerus. Maka dari itu perlunya penguatan berupa pengulangan-pengulangan ${ }^{25}$ dari program pembiasaan harian baik yang sifatnya terjadwal maupun kondisional. Sehingga fungsi dari penguatan tersebut, tidak lain untuk mempertahankan

\footnotetext{
${ }^{25}$ Toeti Soekamto and Udin Saripudin Winaputra, Op.Cit.,
} 
ISTIGHNA, Vol. 3, No 1, Januari 2020 P-ISSN 1979-2824 E-ISSN 2655-8459

Homepage: http://e-journal.stit-islamic-village.ac.id/index.php/istighna

Lia Dwi Tresnani, Muhammad Khoiruzzadi

Program Pembiasaan Harian dalam Membentuk Karakter Siswa Ditinjau dari Perspektif Psikologi Belajar

perilaku yang sudah baik dalam diri siswa SMP Negeri 6 Kota Pekalongan sesuai dengan karakter dari kegiatan pembiasaan harian tersebut. Selain itu, juga akan meningkatkan sedikit-demi sedikit pemahaman baru mengenai pembiasaan yang dibuat oleh sekolah.

Dari program pembiasaan harian yang sudah diterapkan di SMP Negeri 6 Kota Pekalongan, peran dari guru juga amatlah penting dalam pengawasan baik secara langsung maupun tidak langsung. Secara langsung maksudnya adalah mengawasi murid satu per satu, dan jika didapati murid yang melakukan pelanggaran atau tidak melakukan program pembiasaan harian yang sudah dibuat sekolah, guru akan menegurnya pada siswa yang bersangkutan. Secara tidak langsung maksudnya adalah guru mendapatkan laporan baik dari sesama siswa maupun guru lain mengenai ketidakpatuhan siswa pada peraturan yang sudah ada di sekolah. Proses tersebut dengan cara memberi peringatan, teguran, dan bahkan hukuman tidak lain adalah untuk mengarahkan perilaku siswa yang kurang baik untuk menjadi lebih baik dari sebelumnya. ${ }^{26}$

Tidak adil jika guru tidak memberikan apresiasi kepada siswa yang dapat melakukan program pembiasaan harian yang sudah dibuat oleh pihak sekolah. Apresiasi yang diberikan guru kepada siswa bisa berupa kata-kata penyemangat, pujian, dan hadiah. Maka pemberian apresiasi dan hukuman merupakan unsur tambahan yang sifatnya penting ${ }^{27}$ dalam konsep perubahan perilaku siswa. Namun perlu diingat kembali, untuk pemberian hukuman kepada siswa harus bertahap sesuai dengan kesalahan atau pelanggaran yang dilakukan siswa. Pemberian hukuman juga harus bersifat mendidik, bukan malah membuat siswa akan semakin memberontak pada kebijakan yang sudah dibuat di sekolah.

Menurut Skinner hukuman tidak menurunkan probabilitas dari siswa yang melakukan pelanggaran. Walaupun hukuman bisa menekan suatu respons selama diterapkan, namun hukuman tidak akan melemahkan kebiasaan.

\footnotetext{
${ }^{26}$ Syaiful Sagala, Konsep Dan Makna Pembelajaran, Bandung: Alfabeta, 2003

27 Zulhammi, Teori Belajar Behavioristik Dan Humanistik Dalam Perspektif Pendidikan Islam, Jurnal Darul 'Ilmi 3, no. 1, 2015
} 
ISTIGHNA, Vol. 3, No 1, Januari 2020 P-ISSN 1979-2824 E-ISSN 2655-8459

Homepage: http://e-journal.stit-islamic-village.ac.id/index.php/istighna

Lia Dwi Tresnani, Muhammad Khoiruzzadi

Program Pembiasaan Harian dalam Membentuk Karakter Siswa Ditinjau dari Perspektif Psikologi Belajar

Skinner juga berpendapat bahwa hukuman dalam jangka waktu panjang tidak akan efektif, tampak bahwa hukuman hanya menekan perilaku, dan ketika ancaman dihilangkan, tingkat perilaku akan ke level semula. ${ }^{28}$

\section{b. Kesadaran Siswa dalam Berperilaku}

Secara kebijakan dalam peraturan pendidikan di Indonesia mengenai batasan umur anak SMP adalah berkisar antara 11-17 tahun, dan batasan maksimal umur siswa ketika masuk SMP kelas VII adalah umur 15 tahun. $^{29}$ Namun secara umum, umur siswa kelas VII berumur 13 tahun, kelas VIII berumur 14 tahun, dan kelas IX berumur 15 tahun.

Jika dilihat dari sisi umur siswa SMP Negeri 6 Kota Pekalongan, para siswa sudah secara perkembangan kognitifnya masuk dalam tahapan operasional formal dan beberapa siswa masih dalam tahapan operasional konkret. ${ }^{30}$ Pada tahapan operasional konkrit, menandai suatu titik-balik besar dalam perkembangan kognitif siswa. Cara berpikir siswa jauh lebih dari sekedar logika. Ia bersifat fleksibel dan lebih teratur dari sebelumnya. Siswa di tingkatan operasi-operasi berpikir konkret sanggup memahami dua aspek suatu persoalan secara serentak. Di dalam interaksi-interaksi sosialnya, mereka memahami bukan hanya apa yang akan mereka katakan, tapi juga kebutuhan pendengarannya. Selama tahun-tahun bersekolah, siswa menerapkan skemaskema logis untuk lebih banyak tugas. Dalam proses ini, pemikiran mereka tampaknya mengalami perubahan kualitatif menuju suatu pemahaman komprehensif tentang prinsip-prinsip dasar pemikiran logis. ${ }^{31}$ Untuk siswa SMP Negeri 6 kota Pekalongan yang sudah berumur 11 tahun ke atas, mereka pada tahapan operasional formal. Tahap di mana mereka mengembangkan kemampuan berpikir abstrak, sistematis, dan Ilmiah. ${ }^{32}$ Berpikir operasional

${ }^{28}$ Familus, Teori Belajar Aliran Behavioristik Serta Implikasinya Dalam Pembelajaran, Jurnal PPKn dan Hukum 11, no. 2, 2016

${ }^{29}$ Permendikbud Nomor 14 Tahun 2018 tentang Penerimaan Peserta Didik Baru 2018

${ }^{30}$ Jhon W. Santrock, Psikologi Pendidikan, Translated by Diana Angelica, Jakarta: Salemba Humanika, 2009

${ }^{31}$ Laura E. Berk, Development Through The Lifespan, Yogyakarta: Pustaka Pelajar, 2012

${ }^{32}$ Jhon W. Santrock, Op.Cit., 
ISTIGHNA, Vol. 3, No 1, Januari 2020 P-ISSN 1979-2824 E-ISSN 2655-8459

Homepage: http://e-journal.stit-islamic-village.ac.id/index.php/istighna

Lia Dwi Tresnani, Muhammad Khoiruzzadi

Program Pembiasaan Harian dalam Membentuk Karakter Siswa Ditinjau dari Perspektif Psikologi Belajar

formal mempunyai dua sifat yang penting, yaitu: deduktif hipotesis, yakni mengembangkan hipotesa-hipotesa atau perkiraan-perkiraaan terbaik, dan secara sistematis menyimpulkan langkah-langkah terbaik guna pemecahan masalah dan kombinatoris/asimilasi (penggabungan informasi baru ke dalam pengetahuan yang sudah ada) mendominasi perkembangan awal pemikiran operasional formal, dan pemikir-pemikir ini memandang dunianya secara subjektif dan idealis. Semua tahap perkembangan tersebut berlaku serentak pada semua bidang perkembangan kognitif. ${ }^{33}$ Jadi pada tahapan umur SMP, siswa mampu berpikir siapa dirinya dan mampu berbuat sesuai dengan cara berpikir nalarnya mana yang baik dan mana yang tidak baik.

Sejatinya proses perubahan perilaku siswa berdasarkan pengamatan secara langsung sehingga dilakukan peniruan (imitation) dan konsep modelling (percontohan). ${ }^{34}$ Siswa melihat dan mengamati seluruh kegiatan yang ada di dalam program kebiasaan harian tersebut. Jika ada siswa yang berperilaku melanggar atau tidak memasukkan pakaiannya dan berpenampilan tidak rapi, maka akan ada sanksi yang diterima oleh siswa tersebut. Hal ini akan menjadi perhatian bagi siswa yang melihatnya, mereka tidak akan meniru perilaku yang tidak sesuai agar tidak mendapatkan hukuman seperti yang dialami temannya.

Begitu pula sebaliknya, jika ada siswa yang sedang memperhatikan temannya yang sedang diberikan motivasi dan pujian atas keberhasilan dalam melaksanakan program pembiasaan yang ada di SMP Negeri 6 Kota Pekalongan. Siswa tersebut akan berpikir dan menggunakan daya kognitifnya untuk sebisa mungkin meniru apa yang dilakukan temannya yang mendapatkan pujian atau penghargaan tersebut.

Selain itu, peran dari guru sebagai model panutan di sekolah harus diperhatikan betul. Karena guru yang ada di SMP Negeri 6 Kota Pekalongan sedang diamati betul tingkah lakunya oleh siswa-siswinya. Dalam benak

\footnotetext{
${ }^{33}$ Hijriati, Tahapan Perkembangan Kognitif Pada Masa Early Childhood, Bunayya: Jurnal Pendidikan Anak 1, no. 2, 2016

${ }^{34}$ Suryono and Haryanto, Belajar Dan Pembelajaran Teori Dan Konsep Dasar, Bandung: Remaja Rosdakarya, 2012
} 
ISTIGHNA, Vol. 3, No 1, Januari 2020 P-ISSN 1979-2824 E-ISSN 2655-8459

Homepage: http://e-journal.stit-islamic-village.ac.id/index.php/istighna

Lia Dwi Tresnani, Muhammad Khoiruzzadi

Program Pembiasaan Harian dalam Membentuk Karakter Siswa Ditinjau dari Perspektif Psikologi Belajar

pikiran siswa, guru merupakan tauladan yang ideal bagi siswa, karena siswa memandang guru adalah panutan yang berperilaku baik. Jika guru melakukan perbuatan yang tidak baik, ini akan menjadi masalah tersendiri di sekolah. Karena di dalam pikiran siswa, guru yang seharusnya menjadi panutan tetapi malah berperilaku tidak sesuai dengan norma yang ada. Siswa mengalami kebimbangan dan kebingungan, mengenai apa yang hendak siswa lakukan. Jadi perilaku guru di sekolah harus dijaga dengan baik, agar siswa benar-benar menyimpulkan bahwa guru adalah sosok panutan yang memang harus dicontoh.

Inti dari program pembiasaan harian yang bersifat terjadwal maupun kondisional yang ada di SMP Negeri 6 Kota Pekalongan adalah untuk membentuk perilaku siswa sesuai dengan tujuan karakter yang dikehendaki dari setiap kegiatan tersebut. Awalnya siswa melakukan program pembiasaan tersebut karena takut jika tidak melakukannya akan mendapatkan sanksi atau teguran nantinya, sama halnya dengan jika siswa melakukan semua program pembiasaan harian yang ada di SMP Negeri 6 Kota Pekalogan, siswa akan mendapatkan rasa aman dan pujian dari guru atau sesama temannya. Untuk tahap awal memang diperbolehkan dengan konsep tersebut, namun jika berjalannya waktu kemudian cara berpikir siswa masih sama, karena siswa melakukan semua program pembiasaan tersebut dikarenakan adanya "reward" dan "punishment". Maka hal yang ditakutkan adalah ketika siswa sudah lulus dan tidak melakukan proses pembiasaan tersebut, siswa akan berperilaku kurang baik dan bahkan melenceng dari nilai norma dan agama. Jadi siswa perlu dipahamkan dan diberi stimulus untuk melakukan segala program pembiasaan yang sifatnya baik tidak lain dan tidak bukan atas dasar kesadaran dirinya sendiri, bukan karena siswa takut akan teguran atau hukuman dan bukan karena pujian dan hadiah.

\section{KESIMPULAN}

Program pembiasaan harian yang dibuat oleh SMP Negeri 6 Kota Pekalongan bersifat terjadwal dan kondisional, Program pembiasaan harian 
ISTIGHNA, Vol. 3, No 1, Januari 2020 P-ISSN 1979-2824 E-ISSN 2655-8459

Homepage: http://e-journal.stit-islamic-village.ac.id/index.php/istighna

Lia Dwi Tresnani, Muhammad Khoiruzzadi

Program Pembiasaan Harian dalam Membentuk Karakter Siswa Ditinjau dari Perspektif Psikologi Belajar

memiliki sepuluh kegiatan yaitu (1) Tadarus dan doa sebelum KBM (religius dan disiplin), (2) solat dhuha (religius dan tanggung jawab), (3) solat dzhuhur berjamaah (religius dan tanggung jawab), (4) kantin kejujuran (kejujuran), (5) tertib datang dan pulang (disiplin dan tanggung jawab), (6) tertib berpenampilan (disiplin dan tanggung jawab), (7) hormat bendera menyanyikan lagu kebangsaan, dan lagu daerah (cinta tanah air dan semangat kebangsaan), (8) piket kelas berkelompok (peduli lingkungan dan tanggung jawab), (9) pengondisian kebersihan (peduli lingkungan), (10) pemisahan sampah organik dan non organik (peduli lingkungan dan tanggung jawab).

Dari program pembiasaan harian tersebut bertujuan untuk membentuk karakter siswa yang diharapkan bisa dijelaskan dengan menggunakan pendekatan psikologi khususnya dengan teori-teori belajar yang sudah ada diantaranya (1) perubahan tingkah laku siswa dengan kegiatan pembiasaan dan dilakukan secara berulang-ulang akan menjadi penguat dalam perilaku siswa selain itu reward dan punishment sebagai proses pengingat siswa, (2) kesadaran diri siswa dalam berperilaku karena perubahan tingkah laku siswa perlu dilihat dari perkembangan kognitif siswa. Beberapa siswa masih berada dalam tingkatan operasional konkret dan kebanyakan sudah masuk dalam tahapan operasional formal sehingga siswa mampu berpikir secara lebih matang dan mampu berpikir nalar dan logis. Selain itu, perubahan tingkah laku siswa terbentuk karena proses peniruan dan percontohan dari guru khususnya, dan teman-teman di sekolah secara umum. Jadi peran guru, lingkungan sekolah dan kemampuan kognitif siswa menjadi kunci penting dalam pembentukan perilaku.

\section{REFERENSI}

Afifudin. 2012. Metodeologi Penelitian Kualitatif. Bandung: Pustaka Setia

Ayu, Agista Rizky Ridha, and I Made Suwanda. 2013. Pembentukan Karakter Siswa SMP Negeri 6 Mojokorto Melalui Kegiatan Upacara Bendera. Kajian Moral dan Kewarganegaraan, 1, no. 1

Berk, Laura E. 2012. Development Through The Lifespan. Yogyakarta: Pustaka Pelajar 
ISTIGHNA, Vol. 3, No 1, Januari 2020 P-ISSN 1979-2824 E-ISSN 2655-8459

Homepage: http://e-journal.stit-islamic-village.ac.id/index.php/istighna

Lia Dwi Tresnani, Muhammad Khoiruzzadi

Program Pembiasaan Harian dalam Membentuk Karakter Siswa Ditinjau dari Perspektif Psikologi Belajar

Dalimunthe, Reza Armin Abdillah. 2015. Strategi Dan Implementasi Pelaksanaan Pendidikan Karakter Di SMP N 9 Yogyakarta. Jurnal Pendidikan Karakter 5, no. 1

Dalyono, M. 2007. Psikologi Pendidikan. Jakarta: Rineka Cipta

Fadhillah, Muhammad dan Lilif Mualifatu Khorida. 2013. Pendidikan Karakter Anak Usia Dini. Yogyakarta: Ar-Ruzz Media

Familus. 2016. Teori Belajar Aliran Behavioristik Serta Implikasinya Dalam Pembelajaran. Jurnal PPKn dan Hukum 11, no. 2

Frye, Mike. 2002. Character Education: Informational Handbook and Guide for Support and Implementation of the Student Citizent Act of 2001. North Carolina: Public Schools of North Carolina

Hergenhanhn, B.R. Dan Matthew H.Olson. 2010. Theories of Learning, Terj. Tri Wibowo. Jakarta : Prenada Media Group. Jakarta: Prenada Media Grup

Hijriati. 2016. Tahapan Perkembangan Kognitif Pada Masa Early Childhood. Bunayya: Jurnal Pendidikan Anak 1, no. 2

Lickona, Thomas. 1991. Educating for Character: How Our School Can Teach Respect and Responsibility. New York, Toronto, London, Sydney, . Aucland: Bantam books

Marzuki. 2012. Pendidikan Karakter Dan Pengintegrasiannya Dalam Pembelajaran. STAIN Kediri

Mitra, L. Diana, dan Steven Jay Gross. 2009. Increasing Student Voice in High School Reform: Building Partnerships, Improving Outcomes. Educational Management Administration \& Leadership 37, no. 4

Okezone. 2016. SMP Unggulan Pekalongan Kebanjiran Calon Siswa. Berita, $\begin{array}{lll}\text { Accessed } & \text { November } & 2019 .\end{array}$ https://news.okezone.com/read/2016/06/21/65/1421510.

Ramdhani, Ali. 2014. Lingkungan Pendidikan Dalam Implementasi Pendidikan Dalam Implementasi Pendidikan Karakter. Jurnal Pendidikan UNIGA 8 , no. 1

Rismayati, and Rolina. 2012. Pencarian Jati Diri Melalui Proses Belajar Dan Pengalaman. Yogyakarta: SPS UGM

Sagala, Syaiful. 2003. Konsep Dan Makna Pembelajaran. Bandung: Alfabeta 
ISTIGHNA, Vol. 3, No 1, Januari 2020 P-ISSN 1979-2824 E-ISSN 2655-8459

Homepage: http://e-journal.stit-islamic-village.ac.id/index.php/istighna

Lia Dwi Tresnani, Muhammad Khoiruzzadi

Program Pembiasaan Harian dalam Membentuk Karakter Siswa Ditinjau dari Perspektif Psikologi Belajar

Salahudin, Anas dan Irwanto Alkrienchie. 2013. Pendidikan Karakter: Pendidikan Berbasis Agama dan Budaya Bangsa. Bandung : Pustaka Setia

Santrock, Jhon W. 2009. Psikologi Pendidikan,. Translated by Diana Angelica. Jakarta: Salemba Humanika

Sanusi, Anwar. 2016. Metodologi Penelitian Bisnis. Jakarta: Salemba Empat

Slavin, Robert E. 2006. Psikologi Pendidikan: Teori Dan Praktik. Translated by Marianto Samosir. Jakarta: PT Indeks

Soekamto, Toeti, and Udin Saripudin Winaputra. 1997. Teori Belajar Dan Model-Model Pembelajaran. Jakarta: Dikti

Sujarweni, V. Wiratna. Sujarweni, V.Wiratna. 2014. Metodeologi Penelitian. Yogyakarta: Pustaka Baru Press

Suryono, and Haryanto. 2012. Belajar Dan Pembelajaran Teori Dan Konsep Dasar. Bandung: Remaja Rosdakarya

Taylor, L. 1993. Vygotskian Influences in Mathematics Education, with Particular Reference to Attitude Development. Focus on Learning Problems in Mathematics 15

Tirri, Kirsi, and Leila Pehkonen. 2002. The Moral Reasoning and Scientific Argumentation of Gifted Adolescents. Journal of Advanced Academics 13, no. 3

Tokuan, Yuliana Margaretha. 2016. Peran Guru Dalam Pembentukan Kepribadian Disiplin Siswa SMP Negeri 11 Kota Pontianak. Jurnal Pendidikan dan Pembelajaran Khatulistiwa 5, no. 1

Yuniati, Ani, Suyahmo, and Juhadi. 2017. Perilaku Menyimpang Dan Tindak Kekerasan Siswa SMP Di Kota Pekalongan. Journal of Educational Social Studies 6, no. 1

Yohanes, Rudi Santoso. 2010. Teori Vygotsky Dan Implikasi Terhadap Pembelajaran Matematika. Widya Warta 34, no. 2

Zulhammi. 2015. Teori Belajar Behavioristik Dan Humanistik Dalam Perspektif Pendidikan Islam. Jurnal Darul 'Ilmi 3, no. 1 